\title{
Biografia artystyczna i mit \\ (na przykładzie Papuszy J. Kos-Krauze i K. Krauzego)
}

\begin{abstract}
The Subject of the study are cinema biographies of artists. The main point of discussion is the "directed biography", popular biography, existing in wide reception for example polish movie Papusza directed by Joanna Kos-Krauze and Krzysztof Krauze. In the paper used the method of analysis and comparison of various available sources and documents: scientific biography, interviews, press releases, reports and documentaries; particularly inspiring was the method of Panofsky. The aim of the article is not uncovering the truth biographical reality, but its interpretation in the form of ideas, visions of artists in the eyes of other artists (directors, screenwriters). There are important issues is the mythologizing and demythologization elements in a film about Papusza and also functions work: knowledge, education. Aesthetic values are not the subject of research in itself, but they can't be overlooked because the analysis of image and analysis of content movie's reminds analysis of discourse, because of the focus on intertextual relations.
\end{abstract}

\section{Key words:}

biography, myth art, artist-women, Papusza, Romany culture

1 Ewelina Wejbert-Wąsiewicz, Katedra Socjologii Sztuki, Wydział Ekonomiczno-Socjologiczny, Instytut Socjologii Uniwersytet Łódzki, Polska, ewelinaw@uni.lodz.pl. 


\section{BIOGRAFIA I MIT}

Biografie artystów to temat popularny szczególnie dla literatury i kinematografii. Znana historyczka sztuki Maria Poprzęcka uważa nawet, że popularyzacja „świata sztuki” przebiega przede wszystkim droga biograficzną: „Wszelkie formy biograficzne są znacznie łatwiej przyswajalne przez tzw. szeroką publiczność niż jakiekolwiek inne. Sztuka, zarówno jako doświadczenie twórcze, jak też i świadome doświadczenie odbiorcze, jest czymś elitarnym. Takie doświadczenie jest udziałem niewielu, natomiast doświadczenie życiowe - tu żona w ciąży nie wiadomo z kim, a tutaj syfilis, tu skłonność do homoseksualizmu - są dostępne powszechnie. Powikłania życiorysów zrozumie każdy, natomiast nie każdy zrozumie grę kontrastu pomiędzy czerwienią a zielenią [...]” (Kasperowicz, Wolicka, 2005, s. 345).

Trzeba zaznaczyć, że nigdy jednak nie można w pełni poznać człowieka, bo nie mamy dostępu do jego świata wewnętrznego, gdzie jest się samym ze sobą (Szczepański, 1978). Każda działalność ludzka zostawia ślad w świecie wewnętrznym i zewnętrznym. Ślady w świecie zewnętrznym mogą być odczytane, zestawione razem i złożą się na konstrukcję zwaną biografią. Historyczka sztuki Joanna Sosnowska tak ujęła ten problem: „Rzeczywisty człowiek umiera naprawdę, zamykając tekst swojego życia [...] Śledzenie dziejów życia jest lekturą tekstu, który sami tworzymy, jest więc pisaniem, a rezultatem jest to, co powszechnie zwie się biografią, a więc jakaś opowieść zbudowana z tkanki cytatów [...]. Biografia jest opresywna wobec tekstu-życia” (Sosnowska, 2005, s. 181).

W kulturach przedliterackich opowiadania zmagazynowane były w pamięci opowiadających i prezentowane zazwyczaj w formie śpiewu czy poezji pełniły funkcje integracyjne i rozrywkowe. Opowiadający rzadko był autorem historii, częściej zaś pośrednikiem. W kulturach literackich wzmocniła się zarówno pozycja autora, jak i opowiadającego, a zapisane historie można było interpretować na różne sposoby. Spisywanie życiorysów artystów miało miejsce w czasach starożytnych, a w epoce romantyzmu, w okresie szczególnej mitologizacji postaci artysty w kulturze europejskiej, powstawały wyidealizowane portrety literackie (np. Pliniusz Starszy w Historii naturalnej) czy autobiografie (np. Wyznania św. Augustyna (IV-V w n e.)). Zainteresowanie legendami artystycznymi stało się motorem powołania nowego gatunku literatury - powieści o artyście (idealizującej lub odbrązawiającej twórcę). Wśród postaci znanych w kulturze a inspirujących literaturę biograficzną można wskazać władców, naukowców oraz artystów przede wszystkim malarzy, poetów, pisarzy. Kino, naśladując literaturę, z uwagi na swój audiowizualny charakter, jeszcze bardziej skomplikowało kwestię gatunków biografii oraz prawd i mitów artystycznych. Oprócz legend artystycznych chodzi 
tu o naturę kina jako medium zdolnego do mitologizacji ludzi, rzeczy, gestów, wzorów, zachowań, historii itp.(Łotman, 1983). Mitologie gwiazd wzorowane są na dawnych legendach, odgrywanych i przetwarzanych przez społeczności pierwotne. Zdaniem A. Jackiewicza mitologie są nagromadzonymi społecznymi doświadczeniami (1975). Przeszłość, historia ma to do siebie, że ulega mitologizacji. Historia odarta z realności uogólniona zostaje w postaci ciągu wydarzeń o uniwersalnym zasięgu. Coś, co się wydarzyło w konkretnym miejscu i czasie, staje się ponadczasową przypowieścią, która mogła się wydarzyć wszędzie i zawsze. Legenda jako narracja skończona powstaje od początku jako pieśń, jako poezja (Eco, 2008). Mit, jak wiadomo, choć znany bardzo szeroko, rozumieją tylko nieliczni wybrani.

Marek Hendrykowski (2007) w tomie poświęconym pamięci Bolesława Michałka próbował odpowiedzieć na pytanie: czy biografizm jest dążeniem kina współczesnego? Autor zauważył, że już w latach trzydziestych ubiegłego wieku krytycy literatury byli pod wrażeniem ogromnej popularności biografii powieściowej. Z wypowiedzi panelistów konferencji skupiającej historyków literatury i sztuki wynika, że biografie popularnych artystów odegrały w ich przypadku rolę inicjacyjną (Kasperowicz, Wolicka, 2005). Zdaniem M. Hendrykowskiego biografizm jest tendencją, która ujawnia kryzys kina i kultury audiowizualnej. Jego przejawem jest depersonalizacja form widowiska ekranowego, która wynika przede wszystkim z instrumentalizacji sztuki filmowej (instytucje produkcji kinematografii). I choć film biograficzny jest tylko jednym z gatunków, biografizm jawi się jako dążenie sztuki filmowej do przezwyciężenia „kinowej fabryki”.

Ekranowa biografia nie jest całym życiem ludzkim, ale stanowi więcej niż owo życie (Kasperowicz, Wolicka, 2005). Z jednej strony fragmenty życiorysu przetworzone zostają na ekranowy spektakl, co stanowi zaledwie wycinek z życia ludzkiego (wymiar fizyczny, empiryczny). Z drugiej strony komunikat taki wydobywa głębszy sens życia, odnajduje ukryte wymiary istnienia (wymiar metafizyczny). Z tych powodów wydaje się, że „życiopisanie” kamerą nie jest przelotną modą. Kino faktów i kino fikcji jest wtórne wobec biograficznej prawdy. Biografizm zaś realizuje przede wszystkim funkcję poznania człowieka.

Pojęcie mitu artystycznego odnoszę za Marianem Golką (1995), Marią Gołaszewską (1972, 1984) i Andrzejem Osęką (1987) do dyskursów uzasadniających potrzebę twórczości, rolę artysty. Filmy biograficzne o artystach traktuję jako obrazy, dla których osią jest osoba artysty, jego życie lub jego twórczość. Oprócz przedstawienia życia i losu artysty na tle epoki mogą ukazywać relacje człowieka ze sztuką, motywacje artystyczne, proces stawania się artystą, a także społeczny odbiór sztuki (są to pola zainteresowań socjologii sztuki). Warto podkreślić, że 
powstałe o artystach obrazy filmowe można również traktować jako samodzielne i pełnoprawne dzieła sztuki. Dobitnie świadczy o tym choćby film A. Tarkowskiego Andrej Rublov (1966), nazywany arcydziełem kina, czy Edward Munch (1974) Petera Watkinsa, uchodzący za „biografię totalną”.

Filmoznawcy podkreślają, że niezmiernie rzadko w filmach biograficznych pojawiają się próby pokazania genezy dzieł artysty, częściej są nieudane niż udane (Michałek, 1976). Charakterystycznym jest, że ten „udany element” filmowej biografii pojawia się w dziele Andrej Rublow (1966) A. Tarkowskiego, Mr Turner (2014) M. Leigh, a więc w filmach, które uchodzą za arcydzieła. Być może najważniejszym elementem jest tu fakt, iż filmy te są freskami epok i historii, traktatami o sztuce i człowieku.

\section{KINO BIOGRAFICZNE A GATUNKI FILMOWE}

Z perspektywy gatunkowej można wyróżnić filmy biograficzne: a) naukowe (oświatowe) - będące odpowiednikiem literatury naukowej, w tym historycznej; b) film dokumentalny lub reportaż - oparty na autentycznych obrazach rzeczywistości artystycznej; c) film poetycki - oparty na konwencji oddania nastrojów i uczuć artysty z pomocą filmowych środków wyrazu; d) film fabularny bazujący na fikcji. Do powyższych typów filmów biograficznych być może należałoby również dodać film fabularny niefikcyjny, czego przykładem jest Powstanie Warszawskie (2014) w reżyserii Jana Komasy - ufabularyzowane dzieło w całości złożone z dokumentalnych materiałów archiwalnych nagranych przez dwóch młodych reporterów w 1944 roku.

Na osobne omówienie zasługuje film paradokumentalny, który zbliżony do dokumentu jest jednak całkowicie lub w dużej części inscenizowaną narracją wydarzenia, które rozegrało się w przeszłości. Z kolei gatunek nazywany docudramq jest bardziej ufabularyzowaną formą paradokumentu. Najczęściej jest to inscenizacja autentycznych wydarzeń z przeszłości ukazanych w udramatyzowanej formie w konwencji widowiska filmowego, telewizyjnego (Szczurowski, 2007). Docudrama i film paradokumentalny są bliższe wypowiedzi artystycznej niż historycznej narracji biograficznej. Z perspektywy tematu, jakim są biografie artystów, gatunki te pełnią głównie funkcje poznawcze i edukacyjne.

Wypada zaznaczyć, że wspomniany podział na gatunki traktuję umownie, gdyż rozstrzyganie w tej kwestii nie jest zadaniem dla socjologów, lecz filmoznawców, historyków filmu. Wydaje się jednak, że podział na gatunki i typy filmów biograficznych jest wyzwaniem dla samych filmoznawców. Wśród filmów faktu 
M. Hendrykowski wymienia: dokument biograficzny, portret dokumentalny, autobiografię dokumentalną, esej biograficzny, życiorys, reportaż, dziennik intymny pisany kamerą. A w przypadku filmów fabularnych podaje: biografię i autobiografię artysty, legendę, apokryf biograficzny, sagę rodzinną, dramat egzystencjalny (Hendrykowski, 2007, s. 18). Filmoznawca Bolesław Michałek wspomina jeszcze o „eseju biograficznym” (Michałek, 2007, s. 304).

Film jest skomplikowanym materiałem badawczym. Jest to związane choćby ze złożoną strukturą utworu filmowego oraz procesem jego odbioru. Spośród wielu funkcji, jakie pełni dzieło filmowe, podstawową rolą filmu biograficznego jest informacja, poznanie. Film biograficzny nastawiony jest na upowszechnianie określonych treści pochodzących z różnych źródeł oraz na kształtowanie opinii widzów. Charakter tak rozumianej funkcji jest usługowo-społeczny, a czasem bywa propagandowy. Druga istotna funkcja filmu biograficznego nastawiona jest na sposób przekazywania treści, czyli kreację artystów czy autokreację twórców filmu. Istotna z tej perspektywy może być wyobraźnia twórców filmu zawarta w dziele. Filmowa biografia może dostarczyć socjologii materiału i inspiracji do badań i teorii współczesnego społeczeństwa, wreszcie może być analizą społecznych relacji, kulturowym świadectwem społecznych procesów, które analizuje socjologia.

Każde dzieło filmowe można potraktować jako specyficzny rodzaj obserwacji społeczeństwa, w którym narracja służy kondensacji, amplifikacji bądź wyolbrzymieniu procesów społecznych. Tym samym film można traktować jako specyficzne laboratorium zaś jego „społeczne życie” - interpretacje, dyskusje - jako dyskurs, który ujawnia pozycje oraz postawy rozmaitych aktorów społecznych. Dzieło artystyczne jest świadectwem kultury („tekstem”) czy też reprezentacją społeczną o wielu znaczeniach, poddających się analizie socjologicznej. Po drugie, film problematyzuje kwestie, którymi zajmuje się socjologia, odnosząc się czasem wprost, a czasem pośrednio do koncepcji porządku społecznego. Z tej perspektywy film postrzegać możemy jako laboratorium społeczne, w którym jego twórcy sprawdzają normy i praktyki społeczne, a publiczność obserwuje, dyskutuje o granicach norm oraz regułach społecznych praktyk.

\section{FILM BIOGRAFICZNY A DZIEDZINY ARTYSTYCZNE}

Malarze i muzycy to grupy artystów, których życie najczęściej jest ekranizowane. Są to dziedziny, które prawdopodobnie najlepiej dają się zobrazować w kinie ze względu na audiowizualny charakter medium. Oprócz biograficznych filmów fabularnych można wskazać szereg filmów dokumentalnych, edukacyjnych o artystach. 
W Polsce o życiorysach plastyków opowiadają liczne filmy oświatowe realizowane przez WFO w Łodzi np. z cyklu Plastyka, Polska Plastyka Współczesna, życiorysy wybranych najwybitniejszych kompozytorów polskich są tematem dokumentów wydanych w zestawach edukacyjnych Muzyka.

Albumowe wydania o malarstwie zawierają DVD prezentujące sylwetkę i twórczość artystyczną plastyków (np. seria Wielcy Malarze; Mistrzowie Sztuki Nowoczesnej). Na podstawie wszelkich dostępnych źródeł (fotografii, listów, pamiętników, wspomnień, reportaży, wywiadów, książek i innych), odwiedzin ważnych miejsc w życiu artystów i prezentacji dzieł opowiada się historię życia danego artysty. Istnieją też serialowe docudramy o artystach sztuk plastycznych, np. Potęga sztuki (2006). Brytyjski serial opowiada o biografiach siedmiu malarzy, takich jak: Caravaggio, G. Bernini, P. Picasso, M. Rothko, Rembrand, V. van Gogh, David, W. Turner. Narrator w osobie historyka sztuki opowiada w każdym z odcinków o innym artyście i zwraca szczególną uwagę na jego wybrane ważne dzieło.

Do tej pory pisząc o artystach, miałam na myśli jednostkę twórczą, bez uwzględniania czynnika, jakim jest płeć. Historia sztuki pokazuje, że kobiety odgrywały w produkcji artystycznej mniejszą rolę niż mężczyźni. Istniały dwie przyczyny tego zjawiska. Pierwszą - można by z dzisiejszej perspektywy nazwać historyczną, gdyż przejawiała się ogólnie w mniejszym udziale płci żeńskiej w obejmowaniu zawodów artystycznych. Drugi powód tej sytuacji można ująć w kategoriach „barier systemu artystycznego”. Kobiety, jako dysponujące mniejszą autonomią i autorytetem, miały utrudniony dostęp do świata sztuki, a także warunki funkcjonowania, osiągania renomy (Heinich, 2007; Nochlin, 2007).

W Socjologii artysty M. Golka (1995), przedstawiając zmiany statusu twórcy nowożytnego (na przykładzie twórców malarstwa i literatury), tylko raz przywołuje postać artystki Olgi Boznańskiej, gdy cytuje jej list o doskwierającej biedzie i samotności na emigracji (2012). Wprawdzie w bibliografii cytowanych prac odnajdziemy jeszcze Dzienniki Zofii Nałkowskiej, jednakże nawet i one nie są materiałem analitycznym do rozważenia kwestii kariery artystek czy statusu kobiety w polu artystycznym, systemie artystycznym.

Dostrzegalną cechą kinematografii biograficznej jest nikła obecność kobiet w ekranizacjach światów „wielkich artystów”. Wprawdzie realizowane są filmy dokumentalne, oświatowe o artystkach, jednak nie zapewniają one szerokiego obiegu w kulturze. Analiza indeksów kinowych biografii wykazuje, że choć powstają kinowe produkcje o życiu i twórczości sławnych kobiet (np. o Fridzie Kahlo, Edith Piaf, Sylwii Plath, Wirginii Wollf, Marii Callas, Coco Chanell, Camille Claudell, M. Monroe i innych), jest ich mniej niż o artystach (plastykach, np. 
P. Picasso, F. Goya, M. Caravaggio, W. Turner, T. Lautrec, J. Pollock, E. Munch, G. Klimt, Rembrandt, W. van Gogh., A. Modiglani; muzykach, np. A. Mozart, L. van Bethoven, F. Chopin; pisarzach, np. E. Hemingway, A. Rimbaud, P. Varlaine, M. Proust; twórcach popkultury, np. Ch. Chaplin, F. Sinatra, E. Presley i wiele innych). Ta sytuacja nie jest zaskakująca, gdyż wśród nazwisk wielkich artystów zdecydowanie przeważali mężczyźni, jednakże jak podaje N. Heinich (2007), odkąd sztuka stała się powołaniem, wyszła poza granice wolnego zawodu, liczba artystek systematycznie się zwiększała. Jednocześnie instrumenty hierarchii wewnętrznej i zewnętrznej nadal doskonale funkcjonowały, przyczyniając się do faworyzacji męskich karier.

Dobrym przykładem wspomnianej faworyzacji jest tu film biograficzny, ale także kwestia wydawnictw o malarstwie. Albumy o wielkich twórcach polskiego, ale i światowego malarstwa marginalizują bądź pomijają osiągnięcia kobiet. Choć kwestia statusu dzieł malarek polskich w kanonie kulturowym nie budzi wątpliwości, artystki, pisarki, kobiety geniusze nie istnieją w kinowej kulturze dla mas (filmy fabularne). Wyjątkiem jest postać noblistki Marii Skłodowskiej-Curie oraz aktorki Heleny Modrzejewskiej, których życie stało się przedmiotem biograficznych filmów dokumentalnych, fabularnych oraz seriali. Natomiast spośród pisarek polskich chyba tylko życie Elizy Orzeszkowej stało się inspiracją do powstania filmu biograficznego (Ty pójdziesz górq̨, 1978, reż. Z. Skonieczny). Warto dodać, że w Łódzkiej Wytwórni Filmów Oświatowych powstaje obecnie film (Kobro Iwony Siekierzyńskiej) o wybitnej rzeźbiarce Katarzynie Kobro. Życie plastyczek, które osiągnęły sukces międzynarodowy (np. Olga Boznańska, Tamara Łempicka, Zofia Stryjeńska i inne), czeka na ekranizację. Nie inaczej jest w innych dziedzinach sztuki. Najdobitniejszym przykładem jest brak sfabularyzowanej biografii ikony kina niemego, polskiej aktorki Poli Negri (wł. Apolonii Chałupiec). Na tym tle polski film biograficzny Joanny Kos-Krauze i Krzysztofa Krauzego pt. Papusza (2013) wydaje się zamierzeniem szczególnie godnym uwagi.

\section{PAPUSZA - ŻYCIE I MIT}

Bronisława Wajs, nazywana Papuszą (w jęz. romskim lalka) urodziła się w rodzinie romskiej, pochodzącej z grupy etnicznej Polska Roma, w 1908 lub w 1910 roku w Lublinie. Nizinni Romowie wędrowali wówczas w taborach przez Polskę. Zajmowali się zielarstwem, wróżbiarstwem, kowalstwem, muzykowaniem. Po wojnie władze Polski Ludowej przeprowadzały akcje mające na celu likwidację taborów romskich, w wyniku czego Cyganie osiadli w wyznaczonych im miejscach. Pa- 
pusza dorastała w taborze wychowywana przez matkę i ojczyma (ojciec zmarł na syberyjskim zesłaniu, gdy miała 5 lat). Tak jak wszystkie dzieci romskie nie uczęszczała do szkoły, jednak chciała się uczyć. Pierwsze litery, „nie za darmo”, pokazali jej uczniowie wracający ze szkoły. Potem dzięki kradzieżom kur opłacała lekcje nauki alfabetu, następnie uczyła się samodzielnie (w wieku 12 lat). W wieku 15-16 lat wydano ją za mąż, jednakże małżeństwo szybko się rozstało. Drugim jej mężem był starszy o ponad 20 lat Dionizy Wajs, muzykujący na harfie. W późniejszym czasie małżeństwo, nie mogąc doczekać się własnych dzieci, adoptowało chłopca Władysława, którego nazywali Tarzanem (okoliczności i data są nieznane). Papusza tańczyła i śpiewała podczas występów orkiestry cygańskiej Wajsa. Uwielbiała czytać romanse, kochała z wzajemnością młodego Cygana Witolda, który nie mógł znieść jej związku z Dionizym i zażądał od niej porzucenia męża. Papusza, powołując się na wewnętrzny kodeks moralny, wspominała po latach, że cygańska żona nigdy nie zostawia męża. W pamiętniku o rozstaniu napisała: „Coś we mnie pękło. I żyłam jak duch przez następne lata” (Heinich, 2007, s. 46). Wówczas przeżyła pierwsze załamanie nerwowe. Z pewnością okrucieństwa wojny pozostawiły ślad w psychice młodej, wrażliwej kobiety.

W okresie drugiej wojny światowej Romowie najczęściej ukrywali się w lasach, na bagnach (chronili się w prowizorycznych ziemiankach). Społeczność silnie doświadczyła holocaustu. W trakcie wojny Papusza wraz z mężem i towarzyszami niedoli romskiej doznała głodu, chłodu, wojennej tułaczki, chorób (m.in. tyfus plamisty w 1943 r.) $)^{2}$. Była świadkiem wielu śmierci w taborze, a także rzezi Polaków, Cyganów, Żydów. Wydarzenia te wspominała po latach z trwogą i opisała w prozie i poezji.

Tuż po wojnie z cygańskim taborem wędrował poeta i tłumacz - Jerzy Ficowski, który uciekł do lasu przed aresztowaniem za działalność w AK. Papusza swoje poezje nazywała pieśniami, bajkami, nie miała świadomości ich wartości artystycznej. To właśnie za namową Ficowskiego zaczęła spisywać pieśni. On zaś przetłumaczył je w 1949 roku. W wieku czterdziestu kilku lat Bronisława Wajs za sprawą Juliana Tuwima debiutowała na łamach Nowej Kultury (1951). Ten sukces przyćmiony był przez rodzący się konflikt poetki z romską społecznością. W 1950 roku Jerzy Ficowski i Julian Tuwim opowiedzieli w wywiadzie prasowym („Problemy”) o Papuszy oraz o zwyczajach romskich. Wedle J. Ficowskiego najbardziej oburzyło Cyganów tłumaczenie Międzynarodówki na język cygański, a także propagandowy przekaz o budowaniu lepszej przyszłości przez Cyganów

2 Jedzono koninę, której spożywanie jest w kulturze romskiej zakazane. Po wojnie Szero Rom ogłosił za ten czyn amnestię. 
w ZSRR (Kuźniak, 2013). Zdaniem Papuszy przyczyną nienawiści wśród rodzimej społeczności były informacje o obyczajach cygańskich. Jerzy Ficowski próbował ratować poetkę przed samosądem. W „Życiu Warszawy” opublikował listę nazwisk rosyjskich informatorów, jednak społeczność romska nie dała wiary tym wyjaśnieniom. Poetka posądzona o zdradę tajemnic musiała zimą wraz z rodziną uciekać z taboru konnym wozem do Żagania, w wyniku czego cała rodzina ciężko chorowała (grypa, zapalenie stawów). Po kilku latach rodzina osiadła w Gorzowie Wielkopolskim (od 1954 r.). Do kolejnych prześladowań przyczyniło się wydanie książki Cyganie polscy J. Ficowskiego, w której znalazł się słownik cygańsko-polski. Papuszę oskarżono o zdradę kultury, języka i tajemnic życia romskiego. Wykluczono ją ze społeczności Romów, co stało się powodem jej osobistego dramatu ${ }^{3}$.

W listach do J. Ficowskiego ujawniała żal, strach, opisywała szykany, bójki, ostracyzm, jaki spotkał ją i jej rodzinę za sprawą publikacji. Ciągły strach o życie oraz tragiczne warunki bytowe przyczyniły się do pobytu w ośrodkach psychiatrycznych. Z zachowanych listów Dionizego Wajsa do Jerzego Ficowskiego wyłania się obraz chorej nerwowo, zrozpaczonej żony.

Papusza żyła ponad 30 lat jako osoba odrzucona przez „swoich”; wiodła swój żywot w kompletnym opuszczeniu i nędzy, co potwierdzają reportaże z lat 70. i 80. W 1972 roku umarł jej mąż. Po jego śmierci jeszcze bardziej zapadła na zdrowiu fizycznym i psychicznym. Tęskniła za synem Tarzanem, który wyjechał „gdzieś”, założył rodzinę i nie utrzymywał z nią bliskich relacji (Kuźniak, 2013). Ostatnie lata, pełne choroby, cierpienia, przeżyła u rodziny swej siostry w Inowrocławiu (od 1984 do 1987 r.). Tam też została pochowana (zm. 8 lutego).

Powyższą notę biograficzną ułożyłam na bazie dostępnych źródeł zastanych; wyłączyłam z nich poezje, gdyż sądzę, że podjęcie próby rekonstruowania biografii poetki za pośrednictwem jej wierszy to zadanie dla badaczy literatury. Dwa czynniki wydają mi się warte podkreślenia: stopień utrwalonej wiedzy o poetce oraz kwestia archiwaliów. Stan badań do 2013 roku oceniam jako niewystarczający, bo ich efektem były powielane broszury informacyjne o życiu poetki, kalendaria życia i twórczości, opracowane reportaże. Z kolei materiały archiwalne, takie jak ocalałe listy, rękopisy, nie funkcjonowały w szerokim obiegu. Reportaż A. Kuźniak z 2013 roku jest pierwszą monografią wykorzystującą materiały zastane i wywołane (wspomnienia, fotografie, wywiady ze świadkami wydarzeń). Trzeba jednak zaznaczyć, że z powodu upływu czasu (śmierci świadków) nie udało się

3 Jest to najsurowsza kara, jaka może spotkać Romów. 
porozmawiać autorce z synem Papuszy ani innymi ważnymi członkami licznej rodziny Papuszy (np. bracia, krewni męża).

Z perspektywy feministycznej biografia Papuszy jest niesamodzielna, bo jej życie wpisuje się w cudzy życiorys, nie pozwala się zautonomizować i oderwać od biografii protektora, innego artysty - Jerzego Ficowskiego. Biografie plastyczek Anny Bilińskiej-Bohdanowicz i Katarzyny Kobro zostały zawłaszczone przez ich mężów, to znaczy konstruowane z ich punktu widzenia (Bohdanowicz) lub usytuowania w centrum (Strzemiński). Podporządkowanie w biografii może być wyrazem faktycznego podporządkowania w życiu, jednak badaczki autobiografii i narracji kobiecych wykazały, że różnice między autoprezentacjami kobiet i mężczyzn występują bez względu na położenie geograficzne. Nawet kobiety, które osiągnęły wysoką pozycję społeczną, opowiadały o swoim życiu jak pasywne przedmioty, odnosząc się do wydarzeń życiowych innych osób, często swoich mężów, ojców. Z tego powodu historie życia przestały być postrzegane jako dokumentacja „prawdziwego życia”; są odbierane jako konstruktywne akty refleksji dotyczące również kultury, klasy i płci (Björkenheim, Karvinen-Niinikoski, 2006). Joanna Sosnowska, historyczka sztuki, w artykule pt. Biografia kobiet krytycznie podsumowuje zasady tworzenia hagiografii i nowożytnych biografii opartych na modelu Vasariego, które to neutralizowały problemy rodzajowe. Jej zdaniem biografie artystek, „będące produktem wtórnym w stosunku do biografii artystów są zafałszowane po wielokroć” (Sosnowska, 2005, s. 187).

Cyganie w Polsce żyją od XV wieku, jednakże ich kultura jest oralna. Do czasów Papuszy nie istniała literatura cygańska, choć znane były zapisy poezji ludowej. Papusza była nazwana pierwszą świadomą twórczynią poezji. Być może jest to postrzeganie gadziowe. Zdzisław Morawski (por. Kamińska, 1992, s. 52) wspominał, że jeden w wykształconych Romów powiedział mu w rozmowie o Papuszy: „mamy więcej takich poetów, tylko że oni nie ogłaszają swoich wierszy” (Kuźniak, 2013, s. 165).

Wiersze poetki po osiedleniu odzwierciedlają tęsknotę za utraconym życiem, lasem, młodością. W reportażu telewizyjnym Wójcików mówiła: „byliśmy, żyliśmy w prawdziwości”, porównała sytuację Cyganów do ptaków w klatce. Las był dla niej sferą wolności i szczęścia, gdzie po wojnie widoczna była solidarność ludzka, a nie narodowa.

Wedle danych ze spisu powszechnego w 2011 roku w Polsce mieszka ponad 17 tys. Romów, około 40\% z nich ma podwójną identyfikację narodową (polską i romską), większość deklaruje wyłącznie przynależność do narodu romskiego. Papusza swoją polskość podkreślała w wywiadach z dziennikarzami (Kuźniak, 
2013), a w jej poezji szczególnie zachwyca umiłowanie polskiej ziemi, ojczyzny. Z tego powodu powątpiewano w autentyczność poematu (Wajs-Papusza, 1973, s. 8):

Ziemio moja i leśna

Jestem córką twoją [...]

Pójdę ja w góry

Góry wysokie,

Włożę spódnicę piękna, wspaniałą

Uszytą z kwiatów

I zawołam, ile sił będę miała

Polska ziemio: czerwona i biała!

Ziemio moja, byłaś we łzach,

byłaś bólem przebita,

ziemio, płakałaś we śnie

jak Cyganiątko

we mchu ukryte.

Ja cię bardzo przepraszam, ziemio,

za moje pieśni złe,

za cygańskie znaki.

Złóż razem swoje i moje ciało,

po wszystkim, gdy umrę, przyjmij mnie!

Pójdę ja w góry,

góry wysokie

i zawołam, ile tchu [...].

W listach do J. Tuwima i J. Ficowskiego poetka relacjonowała swoje trudne i biedne życie codzienne. Żyła na pograniczu nędzy, upokorzenia i sławy. Kompletnie odrzucona przez Romów, utrzymywała się z wróżb, żebrania. Wiadomo również o trzymiesięcznym stypendium twórczym od resortu kultury i zapomodze, które otrzymała dzięki staraniom Juliana Tuwima. Poeta korespondował z Papuszą, na jej prośbę pomagał załatwić pewne sprawy (np. lepszą opiekę lekarską dla syna w szpitalu), przysyłał różnorodne książki (m.in. poezje, bajki). W 1962 roku romską poetkę przyjęto w poczet Związku Literatów Polskich. Jej wiersze przekładane były na języki: niemiecki, angielski, francuski, hiszpański, szwedzki, włoski. Za życia otrzymała trzy nagrody kulturalne. Na dorobek Papuszy składa się 
z 40 wierszy, wydanych w trzech tomikach poezji, ukazujących się co 20 lat (Pieśni Papuszy ${ }^{4}$, 1956; Pieśni mówione, 1976; Lesie, ojcze mój, 1990) oraz niemiecko-polski tomik pt. Papuscha w niemieckim przekładzie Karin Wolff (Berlin, 1992). Pozostawiła po sobie także prozę, rękopisy pamiętnikarskie (nieopublikowane) dotyczące jej romskiego życia ${ }^{5}$. Choć jej twórczość jest bezcennym zapisem niepiśmiennej kultury, poetka żałowała, że nauczyła się czytać i pisać. Niektóre źródła podają, że Papusza nie miała żalu do Ficowskiego za publikację jej wierszy (Sochaj, 2013). Inne wspominają, że przebaczyła mu dopiero po wieloletnim milczeniu, w liście z 1979 roku (Kuźniak, 2013). Nie znaczy to, że nie spotykała się z nim wcześniej, bo w telewizyjnym reportażu wywiad z nią przeprowadzał sam Ficowski. Rok przed jej śmiercią tłumacz jej poezji w Demonach cudzego strachu prosił ją o wybaczenie (Kuźniak, 2013).

Mitologizacjom artystycznym sprzyjają różne teksty. Jeszcze za życia (w 1974 r.) Jerzy Ficowski i Papusza stali się bohaterami filmu dokumentalnego pt. Papusza (reż. M. i R. Wójcik). Papusza jawi się w nim jako kobieta skromna, drobna, prostolinijna i serdeczna w obyciu. W reportażu otwarcie mówi o natchnieniu jako o snach, ujawnia, że „mowa do niej przychodzi”, ale też podkreśla tę „inność”, wrażliwość. Gdy inni spali, ona nie mogła, bo „gwiazdy, wiatr, las, noc szeptały jej słowa”.

Kolejny dokument bazujący na wspomnieniach, wywiadach i archiwalnych fotografiach powstał w 1992 roku (Historia Cyganki, reż. G. Kowalski), a w 2013 roku Wyd. Czarne opublikowało reportaż poświęcony romskiej poetce (Papusza, A. Kuźniak), w którym autorka wykorzystała wszelkie dostępne materiały (tj. filmy, nagrania wywiadów, ocalałe listy, dokumenty osobiste J. Ficowskiego i Papuszy, artykuły prasowe, nagrania radiowe, fotografie i inne archiwalia6). W latach 80. cygański zespół Terno wystawiał widowisko pt. Papusza, w którym Cyganie przebaczają Papuszy, gdyż dostrzegają, że dzięki poetce romska kultura została ocalona, a Polacy lepiej ją rozumieją. Opowieść można traktować jako nową wersję legendy artystycznej Papuszy. Don Wasyl Szmidt w dwudziestą rocznicę jej śmierci wydał tomik Pasażerowie niebieskiego taboru (2007), który

4 Recenzentami pierwszego tomiku wierszy byli m.in. J. Przyboś i W. Szymborska.

5 Pamiętnik przepisywała na prośbę J. Ficowskiego z luźnych kartek, które prawdopodobnie szczątkowo przetrwały II wojnę światową. Dokładna data powstawania wspomnień nie jest możliwa do ustalenia. Wiadomo, że Papusza pod koniec lat 40. uzupełniała zapiski bądź spisywała wspomnienia od nowa.

6 Szczególnie docenić należy w monografii A. Kuźniak próbę rekonstrukcji wydarzeń na podstawie zachowanych listów Papuszy do J. Ficowskiego (na podstawie archiwum J. Ficowskiego) i jej zapisków pamiętnikarskich oraz rozmów A. Kuźniak z żyjącymi świadkami wydarzeń. 
częściowo został poświęcony Papuszy. Autor we wstępie napisał, że „już dość się nacierpiała, teraz czas na chwałę, która właśnie Jej się należy”. Chwała ta objawia się w upamiętnianiu. Wizerunek poetki widnieje na znaczku i kartce pocztowej, a gorzowską bibliotekę zdobi jej rzeźba oraz pomnik. Być może rację miał Jan Szczepański pisząc o kulcie bohaterów: „tych bohaterów cierpiących bez zadawania cierpień innym cenimy najbardziej” (Szczepański, 1978, s. 17).

Kreowaniu i podtrzymaniu mitu artystycznego sprzyjają bezpośrednie odniesienia twórców natchnionych sylwetką czy dziełem osoby legendotwórczej. W stulecie domniemanych urodzin poetki (w 2007 r.) zorganizowano po raz pierwszy Konkurs Poezji Romskiej im. Papuszy „O złote pióro”. Na coroczny konkurs przysyłanych jest około 200 utworów w różnych językach, co świadczy to tym, że Bronisława Wajs jest inspiracją nie tylko dla autorów o cygańskich korzeniach. Swoje utwory poświęcili jej pisarze lubuscy i poeci gorzowscy. Należy zaznaczyć, że współcześnie wiele utworów romskich dedykowanych jest poetce (np. wiersze Izoldy Kwiek nazywanej „drugą Papuszą”, Karola Parno Gierlińskiego).

Analiza nadesłanych na konkurs w 2009 roku i opublikowanych tekstów (wierszy, fraszek, dramatów, musicali oraz libretta) świadczy o silnej mitologizacji postaci poetki (Muzeum Okręgowe w Tarnowie, 2010). W konkursowych utworach Papusza jest biedną Cyganką, wielką Polką, narodową bohaterką i stworzycielką poezji romskiej. Stałym motywem utworów jest opowiadanie o losie poetki, jej rodzinnych korzeniach, a także obrazy taboru i lasu, który tak wielbiła w swoich „pieśniach”. Zdecydowana większość utworów nawiązuje do tożsamości poetki, jej podwójnej identyfikacji narodowej, czego przykładem może być cykl Fraszek dla Papuszy autorstwa Aleksandry Cichoń (Tarnów, 2010, s. 28-29):

\section{Równy dom:}

„Chciała ażeby Polak i Rom

Budowali w Polsce równy dom”.
Chopin - 200 Papusza - 100:

„Oj udało się Papusze.

Z tym jubileuszem”.

Nie tylko literatura i kino podtrzymują legendę Papuszy. W 1994 roku Jan Kanty-Pawluśkiewicz wystawił oratorium w języku romskim Harfy Papuszy. Fragmenty dzieła zostały wykorzystane w filmie duetu Krauzów; muzykę nagrodzono na 38 Festiwalu Filmowym w Gdyni. Kompozytor przełożył na uniwersalny dla ludzkości język, jakim jest muzyka, poezję romskiej wyklętej dziewczyny. Krytyk W. Kocołowski w wydaniu płytowym napisał, że autor „przy pomocy muzyki dokonał prywatnego procesu beatyfikacyjnego pewnej skromnej Cyganki, która wędrowała z taborem, uniknęła zagłady, osiadła z przymusu, pisała z serca i kochała świat, choć świat jej nie kochał”. 
Podstawowe fakty biograficzne, takie jak: data urodzin, okoliczności i data zawarcia związków małżeńskich, historia losów rodziny poetki (dziadkowie, ojciec, bracia i siostry), okres wojny w lasach wołyńskich, doświadczenie przez rodzinę holokaustu, okoliczności i data adopcji syna są niejasne, bo jak wszystko w kulturze nomadów niezapisane. Pewną datą jest jedynie dzień śmierci poetki. Nie tylko brak jest źródeł potwierdzających życiorys Bronisławy Wajs, ale sami Wajsowie tworzyli liczne opowieści o swoim życiu. Jedną z nich jest choćby opowiadana w kilku wersjach legenda o harfie, której dźwięk albo kształt (harfa jako kulomiot) uratował im życie w trakcie wojennej ucieczki przed Niemcami (por. Kuźniak, 2013). Wedle źródeł zastanych Papusza była osobą niezwykle wrażliwą, a przede wszystkim inną, bo uczącą się i marzącą o wykształceniu syna. Rozdarta wewnętrznie między poczuciem wolności, jakie dawało życie w lesie, a ambicjami o lepszym życiu, w rządowej akcji osiedlaniu taborów widziała możliwość spełnienia swoich pragnień. „I będą Cyganie żyć jak uczciwi ludzie” - pisała w liście z Żagania 28 listopada 1952 roku do J. Ficowskiego (Kuźniak, 2013, s. 139). Jej inność wyrażała się także w obyciu. Mówiono, że w stosunku do „obcych” była dobra, nie chytra (Machowska, 2011; Kuźniak, 2013). Cechy charakteru Papuszy, jej sposób życia nie mogły spotkać się z uznaniem własnej grupy. Jednocześnie trzeba podkreślić, że w patriarchalnej społeczności romskiej bezpłodna kobieta traktowana była z pogardą, a przemoc wobec kobiet była normą?

Wrażliwość i związana z tym intensywność przeżywania świata jest cechą wyróżniającą artystów, szczególnie malarzy i poetów (Dilthey, 1982). Wiliam Dilthey uważał, że to niebezpiecznie widzieć więcej i głębiej. Mit wyjątkowości artysty mówi o postrzeganiu świata w sposób niezwykły. Podkreślana jest tu szczególnie nieprzeciętna natura twórcy. Artysta to z jednej strony indywidualista, z drugiej - wrażliwy odmieniec, przypominający czasem szaleńca. Niepowtarzalność i jednostkowość artysty podkreśla mit indywidualności, który zdaniem M. Golki (2008) wyraża się w nowości i oryginalności samego przesłania twórcy jak i formy. W legendę tę wpisana jest negatywna konsekwencja drogi indywidualisty w postaci braku zrozumienia środowiska. Mit odrzucenia mówi o samotności artysty, która jest wynikiem dezaprobaty społecznej, przejawiającej się w odrzuceniu zarówno dzieł, jak i samej jednostki twórczej. Rozgrywa się w trzech wymiarach: społecznym, ekonomicznym i moralnym. Odrzucenie rozpowszechniła XIX-wieczna cyganeria artystyczna, prowokująca odbiorców zachowaniem, strojem. Wedle niektórych

7 Przemoc była normalnym elementem życia kobiet cygańskich; odgrywana przemoc istniała w najwcześniejszych zabawach Papuszy „w męża i żonę”. Papusza była bita przez męża Dionizego Wajsa, jej matka z kolei przez ojczyma, a ciotki przez mężów (por. Kuźniak, 2013, s. 18, 39). 
mit ten był owocem megalomanii artysty bądź braku powodzenia. W omawianym przypadku romskiej poetki odrzucenie istniało we wszystkich wymiarach.

Biografia artysty jest portretem, ale może być też portretem zbiorowym epoki. Jej celem powinno być poznanie, a nie idealizacja. Jak wskazują historiografowie, tabu obyczajowe obejmowało kwestie seksualności, chorób i nałogów osób publicznych (Kudelska, 2005). W Polsce sferę zachamowań rozszerza tabu patriotyczne. Dorota Kudelska tak mówiła o tej sprawie: „banalnie mówiąc, malarz treści patriotycznych nie musi okazać się porządnym człowiekiem” (Kudelska, 2005, s. 268). Upowszechnienie biografii poprzez film biograficzny naruszyło wspomniane tabu, ale tylko odnośnie do artystów o mniejszej randze. Z jednej strony film biograficzny sprawił, że to, co było zakazane, już nie jest (Kudelska, 2005), ale z drugiej strony, jak przyznał historiograf Waldemar Okoń, „celowo dodaje się do życiorysu artystów pikantnych faktów biograficznych, żeby stał się bardziej ludzki [...], ale przy naprawdę wielkich artystach granica tabu jest dość wyraźnie określona [...], mówię tutaj głównie o polskich artystach i polskich biografistach. [...] Oczywiście te sprawy seksualne i sprawy religijno-narodowe były zawsze najostrzej obwarowane” (za: Kudelska, 2005, s. 345-346). Mitologizacja, tradycja legend, stała zatem na straży konwencji biografii. Niszczenie dokumentów, manipulacja archiwaliami w służbie mitu były charakterystyczne dla samych artystów, członków rodziny twórców i ich biografów, a nawet historyków sztuki (Kudelska, 2005). Warto zwrócić uwagę na elementy pomijane i uwidocznione przez biografa Papuszy Jerzego Ficowskiego. Legenda obejmuje przede wszystkim jej inność i odtrącenie, ostracyzm. Nieeksponowanymi faktami w biografii Papuszy autorstwa Ficowskiego są liczne pobyty w szpitalach psychiatrycznych ${ }^{8}$, kradzieże, sprawy sądowe (Kuźniak, 2013) i pobyty w więzieniu9 zaś prawdziwym tabu wieloletnia niemoc twórcza, relacje małżeńskie. Z kolei tajemniczość życiorysu poetki i analfabetyzm wydają się podstawą mitu wyjątkowości artystki. Powszechny odbiór tej legendy wzmacniał fakt, że Papusza była Cyganką, którą przedstawiano jako pierwszą świadomą poetkę cygańską. To z kolei przyczyniło się do stworzenia legendy personalnej, która formowana była zarówno przez środowisko literatów, krytyków, odbiorców, jak i przez społeczność romską. Nazwisko Papuszy było znane nawet bez znajomości jej dzieł i wywoływało zarówno pozytywne, jak i negatywne emocje. Poetka zaliczona została do sześćdziesięciu najważniejszych Polek w dziejach kultury.

8 Od lat 50. poetka leczona była w różnych szpitalach psychiatrycznych w Polsce. Najwcześniej znane karty chorobowe informują o rozpoznaniu histerii.

9 Już jako znana poetka w 1957 roku została skazana za kradzież kury na miesiąc aresztu. 


\section{FILM O PAPUSZY - MIĘDZY MITEM A ŻYCIEM}

Bolesław Michałek w 1974 roku opublikował esej, w którym, na podstawie analiz filmów biograficznych powstałych w ciągu trzech dekad (1950-1970), zaprezentował trzy typy filmów biograficznych wedle konfliktów, jakich doświadczały główne postaci. Były to trudne wybory bohaterów: a) pomiędzy posłannictwem a życiem osobistym (miłość, rodzina), które odwodzi twórcę od misji; b) pomiędzy bohaterem a naturą (walka z chorobą, z czasem, ze słabościami); c) pomiędzy misją bohatera a społeczeństwem, władzą, otoczeniem. Ostatni typ sporu był zdaniem B. Michałka najbardziej charakterystycznym elementem dramatu w filmach biograficznych o artystach. Film Papusza jest również zbudowany na tego rodzaju konflikcie, a raczej na jej personalnym micie, bo też trudno mówić w tym przypadku o misji poetki. Papusza jest typem artystki amatorki, która pod jakimś wewnętrznym przymusem, instynktownie układa wiersze. Jej osobowość twórcza przerasta osobowość podstawową (Gołaszewska, 1972). W oficjalnie przekazywanej legendzie jest nieświadoma swego talentu, a po „odkryciu” jej zdolności przez Ficowskiego nie wykazuje szczególnego zainteresowania losami swych wierszy. Z perspektywy wydarzeń potwierdzonych przez liczne źródła kwestia świadomości artystycznej jest zagadkowa, gdyż z jednej strony charakteryzowała ją obojętność wobec własnej twórczości, a z drugiej strony korespondowała z J. Ficowskim i J. Tuwimem. Trzeba jednak dodać, że publicznie nie ceniła swoich wierszy (negacja roli w trakcie wywiadów). Jej „odkrywca” Jerzy Ficowski podawał, że nie wykazywała zainteresowana tłumaczeniami swojej poezji na inne języki europejskie ani hasłem „Papusza” w encyklopedii. Istnieją przekazy (Ficowskiego i Dionizego Wajsa), że spaliła swoje brudnopisy (prawdopodobnie pamiętnikarskie zapiski), późniejsze wiersze, a także korespondencję z Tuwimem i Ficowskim. Nawet gdy otrzymywała nagrody literackie, kwestionowała ich zasadność (por. Kuźniak, 2013). Dziwiło ją honorarium autorskie za wydane wiersze, czemu dawała wyraz w listach do J. Ficowskiego. W rozmowach z reporterami w latach 70. widoczne jest jej poczucie niższości: „ja nic nie umiem, nie mam nauki”. Te zachowania „kafkowskie” wpisują się w legendę antyartystyczną (por. Gołaszewska, 1984). Równocześnie należy dostrzec, że układanie wierszy, pieśni nie było w oralnej kulturze romskiej czymś nadzwyczajnym, a wróżenie czy „chodzenie do miasta i wsi, aby dostać coś do zjedzenia”, było pracą godną i docenianą zarówno przez Cyganów, jak i samą Papuszę ${ }^{10}$.

10 Bronisława Wajs wstydziła się otrzymywać pieniądze za wiersze czy wykorzystywać swój status poetki do poprawy warunków bytowych swej rodziny. 
Spośród kilkudziesięciu mitologii artystycznych funkcjonujących w kulturze europejskiej od wielu wieków w legendę Papuszy wpisują się cztery dyskursy: mit wyjątkowości, indywidualności, odrzucenia i samotności (Osęka, 1987; Golka, 1995, 2012). Jak zauważa Grażyna Stachówna, w biografiach filmowych największą wagę ma beletryzacja życia bohaterów, która dokonuje się w oparciu o selekcję danych oraz subiektywny przekaz ich przedstawienia. Powodem tego są dbałość o atrakcyjność dzieła dla widzów oraz pragnienie wykreowania własnej, „właściwiej” wizji życia bohatera. Wśród biografii literackich i filmowych badacze wyróżniają popularne elementy konstrukcji fabuły; są to: wątki romansowe, stracone szanse i nieoczekiwane sukcesy, przypadkowa ingerencja losu, ekspozycja wydarzeń patriotyczno-militarnych oraz uznanie wielkości życia i dzieł bohatera, choćby już po jego śmierci (Szczepański, Kłos, 2007, s. 122). Dzieło Joanny i Krzysztofa Krauzów wykorzystuje tylko dwa ostatnie „popularne elementy” konstrukcji filmowych biografii. Film pozostaje wierny legendzie Papuszy. Tworzy również inne legendy odnośnie co do poetki. Jedną z nich jest mitologizacja bezpłodności. To Papusza w noc poślubną przerażona perspektywą życia ze starszym mężem modli się do natury: Lesie mój... Lesie mój umiłowany. Zamknij mi łono. Różne źródła podają sprzeczne informacje na temat relacji małżeńskich poetki. Wiadomo z listów Wajsa do Ficowskiego, że Dionizy sprzedał harfę, narzędzie swej pracy, aby ratować żonę, a także wyrażał obawy o jej zdrowie i życie. Z kolei twórcy filmu wybierają inną historię relacji małżeńskiej, pokazują Dionizego jako surowego męża, despotę, którego się bała. W ten sposób wzmacniają legendę personalną Papuszy. W wywiadzie z poetką w 1978 roku małżeńska dola ujęta została przez nią w taki sposób: „U nas miłość inna była; kochała, nie kochała, musiała być dobra dla męża”.

Jak już wspomniano wcześniej, rzadko w filmach biograficznych pokazany jest proces twórczy, geneza dzieł. W analizowanym tu utworze filmowym również brak obrazów natchnienia, ukazania chwil tworzenia wierszy. W jednej ze scen bohaterka przedstawiona jest jako pisząca jakiś list. W innym miejscu jej wiersz czyta zachwycony tą poezją Julian Tuwim. Wybrane wydarzenia z życia artystki ukazane są z dystansu na tle epoki i własnej społeczności. Film opowiada o poetce, ale jest ona tylko ikoną służącą do pokazania historii Cyganów w Polsce na przestrzeni minionego wieku, w tym szczególnie destrukcyjnego dla ich kultury procesu osiedlenia. Dzieło ukazuje pozytywne i negatywne stereotypy na tle wzajemnych relacji Cyganów i „gadziów” "11; ma też być pamięcią, której Romowie

11 Krytycznie o filmie wypowiadał się znany cygański muzyk Don Vasyl, który twierdził, że 
nie mają. Romowie są grupą narodową, która procentowo ucierpiała najbardziej w trakcie hitlerowskiej eksterminacji (około 90\% zginęło) ${ }^{12}$. Zagłada Cyganów, ich świata pozostaje najważniejszym, obok losów Papuszy, elementem konstrukcji filmu. Film jest epitafium dla kultury Innego, który w zetknięciu z Obcym zyskuje sławę i traci szacunek „swoich”. Widzowi towarzyszy wszechobecny dystans, przypomina to oglądanie filmowego świata jakby z okna. Ta sytuacja odbiorcza spotęgowana jest przez czarno-białą kolorystykę, przewagę planów ogólnych i retrospektywny montaż. Symboliczną sceną jest koda końcowa, gdy Papusza patrzy na odchodzącego Ficowskiego, po chwili zza szyby przesłoniętej firanką wpatruje się w dal, spogląda na widzów. Scenę zamyka jadący drogą tabor w planie ogólnym, a całość zamyka muzyczna klamra, utwór śpiewany przez Elżbietę Towarnicką do wiersza Papuszy pt. Krwawe łzy. Jest to jedyny utwór, który w tamtych czasach nawiązywał do holokaustu Romów (Wajs-Papusza, 1956):

\author{
Ile głodów! Ile bied! \\ Tyle smutków! Dróg niemało! \\ Tyle ostrych kamieni w stopy się wbijało! \\ Ileż koło uszu kul nam przeleciało! \\ Ile błot! Jakie deszcze! \\ Ile krwawych łez jeszcze! \\ Ile włosów z głów, z warkoczy \\ rwały nam gałęzie w nocy!
}

Scena filmowa, gdy poetka siedzi w ciemnościach przy płomieniu świecy, łudząco przypomina znany w ikonologii cykl obrazów Georges’a de la Tour Maria Magdalena. Maria Magdalena to postać niosąca przesłanie o wartości i godności kobiet. Zarówno biblijni badacze, jak i historycy świeccy zgadzają się co do tego, że była ona uczennicą Jezusa, którą ten wywyższył ponad apostołów, gdyż to jej jako pierwszej ukazał się zmartwychwstały. W ikonografii przedstawiana była zazwyczaj jako wierna uczennica pogrążona w bólu pod krzyżem, piękna kobieta o długich włosach lub niewiasta pokutująca. Na obrazie Georges’a de la Tour, podobnie jak i w filmie, postać siedzącej, zamyślonej, pokutującej kobiety wyłania się z ciemności. W różnych wersjach tego obrazu towarzyszą jej świeca - symbol

utrwala negatywne stereotypy: „Tak zrobili Państwo Krauze, którzy cofnęli nas do czasów, kiedy myśmy kury kradli, oszukiwali, kiedy byliśmy brudni, wędrowaliśmy” (Spyrka, 2013).

12 W powojennych procesach norymberskich przestępstw na Cyganach nie uznano za ludobójstwo. 
przemijania, ale i nadziei, czaszka - symbol śmierci, lustro - symbol prawdy. Dojmującym nastrojem malarskiego i filmowego obrazu jest smutek.

Film Papusza może być inspiracją do analiz z perspektywy systemu, pola artystycznego (Golka, 2008), sukcesu artystycznego (Heinich, 2010), a także dziedzictwa kultury narodowej, żydowsko-polskiej, cygańsko-polskiej. „To będzie spisek dwóch poetów, żeby ocalić trzeciego" - powiedział filmowy Tuwim do „odkrywcy Papuszy”. Szczególnie wymowny jest obraz w kolejno następujących po sobie scenach prezentujących mieszkania trójki poetów: rudery Papuszy, dalej przytulnego warszawskiego mieszkania Ficowskiego i na końcu wytwornego gabinetu Tuwima. Wątkiem inspirującym jest także udział Romów w cyganerii artystycznej, w bohemie, w której obracają się muzykanci cygańscy, wreszcie rola młodopolskiego artysty-cygana (Golka, 1995; Heinich, 2007). Twórcy filmu biograficznego o romskiej poetce mają już w dorobku inny, wielokrotnie nagrodzony biograficzny film: Mój Nikifor. Wspólnym elementem biografii artystów amatorów jest dyskurs uzasadniający potrzebę tworzenia. Ponadto zarówno Nikifor, jak i Papusza reprezentują mniejszości etniczno-narodowe Łemków i Romów, a także są odmieńcami, odrzutkami społecznymi, osobami słabszymi w kulturze patriarchalnej - niepełnosprawnym mężczyzną i kobietą. Kultura romska wymaga od kobiety posłuszeństwa wobec starszyzny i męża. Płeć poetki jest podkreślonym w filmie czynnikiem opresyjnym. Z perspektywy feministycznej Papusza to film o kobiecie, która wystąpiła przeciw obowiązującym w jej społeczności normom, miała silną potrzebę tworzenia i determinację wewnętrzną. Na okładce wydania płytowego Agory czytamy: „Papusza. Niezwykła historia wyjątkowej kobiety, która miała odwagę być sobą”. W jednym z wywiadów Joanna Kos-Krauze potwierdziła feministyczną interpretację, a o bohaterce powiedziała, że „ma odwagę wyrazić siebie i płaci za to potworną cenę” (Rosicka, 2014). Z kolei Krzysztof Krauze dodał: „wszędzie tam, gdzie kobiety są lepiej traktowane, poziom cywilizacyjny jest wyższy”. Twórczy duet reżyserski deklaruje przywiązanie do kina społecznie zaangażowanego, opowiadającego o polskiej rzeczywistości ${ }^{13}$.

Z perspektywy krytyki filmowej można uznać, że film Papusza zebrał pozytywne recenzje, jednak nie został doceniony na najważniejszym polskim festiwalu filmowym w Gdyni. Dzieło kultury uznane zostaje za arcydzieło, gdy zdaniem odbiorców, publiczności jest doskonałe w swoim gatunku. Dzieło musi wytrzymać „próbę czasu”, a także trwać w świadomości zbiorowej dzięki trudowi lektury

13 Film rozpoczął dyskusję na temat wykluczenia Cyganów i ich kultury z oficjalnej historii i obiegu kulturowego. Następnymi działaniami były wystawy fotografii o życiu Romów w Zachęcie i Narodowym Centrum Kultury w 2013 roku. 
i interpretacji (potencjał wielointerpretowalności). Liczne utwory dopiero po wielu latach uznano za arcydzieła. Agnieszka Graff taki los przepowiada filmowi Papusza (Graff, 2014). A społeczność cygańska jest w tej kwestii podzielona, o czym świadczy jej udział na planie filmowym oraz krytyka filmu (Spyrka, 2014). Gwiazda muzyki cygańskiej Don Vasyl wyraził żal, że w filmie nie ma muzyki cygańskiej: „Czy nie mieliśmy wybitnych cygańskich muzyków, żeby jakaś prawdziwa pieśń w tle była?”14. Okazuje się, że pewne tabu zostało przełamane. Prawdziwe oburzenie wywołała scena pocałunku poetki z tłumaczem: „Tego nigdy nie było. [...] U nas tego nie wolno pokazywać” (Spyrka, 2014).

Widzowie polskich kin w 2013 roku mieli do wyboru kilkanaście tytułów. Wedle danych Box Office (PISF) tylko co piąty widz wybierał w kinie film polski (ogółem 7,16 mln widzów w 2013 roku). Film o romskiej poetce nie znalazł się w pierwszej dziesiątce polskich hitów. Oglądalność Papuszy w kinach nie była wysoka (94 tys. widzów), ale wielokrotnie nagradzana na zagranicznych festiwalach Ida Pawła Pawlikowskiego miała jeszcze mniejszą frekwencję (55 tys. widzów). Dla porównania Drogówka zgromadziła ponad 1,015 mln, a Wałęsa. Człowiek nadziei - 0,956 tys. Kino ambitne, doceniane przez krytykę, ma swoją wierną publiczność, jednak trudno jest mu zaistnieć w szerokim obiegu, przegrywa z amerykańskimi superprodukcjami dla dzieci i młodzieży.

\section{PODSUMOWANIE}

W artykule wiele miejsca poświęcono biografii Papuszy - zarówno filmowej, jak i utrwalonej w piśmiennictwie, literaturze. Ekranizacja drogi życiowej poetki popularyzuje kulturę cygańską, która w Polsce wciąż nie jest dostatecznie znana. W kulturze oralnej Romów o Papuszy opowiadano przy okazji spotkań członków społeczności. W ten sposób dokonywała się integracja środowiska, ale przekazy o poetce dostarczyły również rozrywki. W kulturze literackiej Bronisława Wajs pojawiła się za sprawą „obcego” J. Ficowskiego. Postać cygańskiej poetki zaistniała w kulturze medialnej dzięki dziennikarzom, dokumentalistom, reporterom, fotografom, muzykom, tancerzom. Również popkultura wykorzystała mityczną postać Papuszy (produkcja znaczków, notesów, toreb, odzieży i innych gadżetów

14 „Ten film jest nudny. Tam aż się prosi, żeby muzyka cygańska była w tle, bo tam na końcu dopiero muzyka się pojawia, i to nie wiadomo, czy to z gruszki, czy z pietruszki. I poszły na to grube miliony. Aż się wierzyć nie chce...” (Spyrka, 2014). 
z wizerunkiem poetki). Film Papusza małżonków Krauze jest kolejnym tekstem kultury. Z racji osiągnieć twórców ma on zasięg ponadlokalny (nagrody).

Opowieść o Papuszy zmieniła się w ciągu półwiecza. Papusza była pierwszą, która zapisała słowa i przekazała swoją poezję następnym pokoleniom. Dopuściła się zdrady wedle współplemieńców (opowieść romska). Po latach jej postać jawi się jako heroina walcząca z ciemnotą i analfabetyzmem, w których upatruje źródła biedy swojego narodu (legenda literacka i filmowa). Skazana na ostracyzm środowiskowy cierpi za innych (za tych, którzy pisać już będą mogli). W micie „gadziowym” jest artystką świętą, męczennicą. Jeśli biografię traktować jako konstruktywny akt refleksji dotyczący kultury, klasy i płci (Björkenheim, Karvinen-Niinikoski, 2006), jej historia ma uniwersalny zasięg. Papusza jest kobietą, a więc istotą gorszą w patriarchalnej kulturze, bierną, niezaangażowaną. Brak autorytetu i słaba autonomia są charakterystyczne dla kobiet w ogóle. Jej biografia artystyczna nie może się zautonomizować (ważną funkcję pełni tłumacz, odkrywca J. Ficowski, a poza tym dla niej samej rola żony, matki ważniejsza była niż poetki).

Obraz filmowy stanowi wobec tekstu biografii nową jakościowo propozycję. Film jest artystyczną wizją o innej artystce. Papusza Joanny i Krzysztofa Krauzów może być odczytaniem biografii w wariancie uogólniająco-historycznym (akcentującym przynależność bohaterki do zdarzeń historycznych, określonego kontekstu lokalnego) i uogólniająco-modelowym (wyodrębniającym elementy ponadczasowości i uniwersalizmu treści) (por. Szczepański, Kłos, 2007, s. 181). Jest to obraz wyidealizowany (np. Cyganie w ogóle nie kradną), dominuje w nim perspektywa epicka, czyli makrohistoryczna. Idealistycznie pokazana bohaterka jest oderwana z poziomu personalnego, cielesnego, ale kwestie seksualne z reguły są tabu w biografiach wielkich artystów (Kasperowicz, Wolicka, 2005). Siła retoryczna filmu, a więc to, jak stara się przekonać widza do zawartej w dziele interpretacji, jest duża. Papusza jest kobietą skrzywdzoną, ale i „świętą”. Ten aspekt „świętości”, jak i forma filmu Papusza przypomina dzieło A. Tarkowskiego o świętym malarzu ikon Andriej Rublow. Obraz filmowy Papusza zrealizowano w konwencji czarno-białej, z muzyką Jana Kantego-Pawluśkiewicza, z przewagą statycznych kadrów na planach ogólnych i średnich, ale co najważniejsze, w języku romskim (z polskimi napisami). Warto podkreślić współtworzenie filmu przez Romów, którzy nie tylko wystąpili w filmie, ale także doradzali ekipie filmowej, uczyli języka, zwyczajów. Język i pismo, a zatem pamięć i niepamięć wydają się tworzyć konflikt filmu. „Papusza” jest wehikułem czasu, rekonstrukcją rzeczywistości polskiej i cygańskiej, a z racji zaangażowania Romów w tworzenie filmu - dialogiem kulturowym, próbą pojednania. Choć krewny poetki, znany cygański muzyk, w wywiadzie dla „Dziennika Zachodniego” ujawnia podziały 
i konflikty społecznościowe na tym tle, podkreśla interesowne podejście reżyserów (oraz J. Ficowskiego) do postaci Papuszy. Dla muzyka najbardziej oburzający jest fakt, że twórcy filmowi nie konsultowali obrazu z królem, Radą Starszych oraz z „cywilizowanymi Romami”. Można jednak mieć wątpliwość, czy gest ten, oprócz zamachu na wolność artystów, nie byłby także cenzurowaniem ,jakiejś prawdy”. Twórcy zadbali o oryginalne elementy scenografii (wypożyczone z muzeów wozy taborowe) i kostiumy. Kadry filmowe wiernie oddają trud i urok dawnego życia cygańskiego, znanego m.in. ze starych fotografii zgromadzonych w Muzeum Etnograficznym w Tarnowie. Widać, że autorzy biograficznego filmu odbyli staranną kwerendę archiwalną, a edukacja widzów, poznanie kultury Innego były dla nich najważniejszymi kwestiami.

\section{Literatura:}

Bartosz, A. (red.). (2010).O złote pióro Papuszy. Tarnów: Muzeum Okręgowe.

Björkenheim, J., Karvinen-Niinikoski, S. (2006). Biografia narracja i rehabilitacja. W: A. Golczyńska-Grondas, Ł. Dunajew-Tarnowska (red.), Metoda biograficzna w doradztwie zawodowym i pracy socjalnej (s. 63-86). Łódź: Łódzkie Towarzystwo Naukowe.

Dilthey, W. (1982). Pisma estetyczne. Warszawa: PWN.

Eco, U. (2008). Sztuka. Kraków: Wydawnictwo M.

Golka, M. (2012). Socjologia artysty nowożytnego. Poznań: Wyd. Ars Nova.

Golka, M. (1995). Socjologia artysty. Poznań: Wyd. Ars Nova.

Golka, M. (2008). Socjologia sztuki. Warszawa: Wydawnictwo DIFIN.

Gołaszewska, M. (1984). Estetyka i antyestetyka. Warszawa: Wiedza Powszechna.

Gołaszewska, M. (1972). Kim jest artysta. Warszawa: WSiP.

Graff, A. (2013), Papusza - nie ma prawdy totalnej. Pobrane z: http://www.krytykapolityczna.pl/artykuly/film/20131127/graff-papusza-nie-ma-prawdy-totalnej.

Gwóźdź, A. (2010). Kino po kinie. Film w kulturze uczestnictwa. Warszawa: Oficyna Naukowa.

Hendrykowski, M. (2007). Biografizm jako dążenie kina współczesnego. W: T. Szczepański, S. Kołos (red.). Biografistyka filmowa. Ekranowe interpretacje losów i faktów (s. 11-24). Toruń: Wydawnictwo Adam Marszałek.

Heinich, N. (2007). Być artystą. Rzecz o przekształceniach statusu malarzy i rzeźbiarzy. Warszawa: Vizja Press\&It.

Heinich, N. (2010). Socjologia sztuki. Warszawa: Oficyna Naukowa s.c.

Jackiewicz, A. (1975). Antropologia filmu. Kraków: Wydawnictwo Literackie.

Kamińska, K. (1992). Papusza, czyli Wielka tajemnica. Gorzów Wielkopolski: Wydawnictwo Rolland.

Kasperowicz, R., Wolicka, E. (red.). (2005). Biografia, historiografia dawniej i dziś. Biografia nowoczesna nowoczesność biografii. Lublin: TN KUL. 
Kołos, S. (2013). Człowiek i sztuka. Pobrane z: http://www.filmoteka szkolna.pl/uploaded/ lessons/broszura/7efdb73a.pdf.

Kudelska, D. (2005). Lepsza i gorsza biografia. W: R. Kasperowicz, E. Wolicka (red.). Biografia, historiografia dawniej i dziś. Biografia nowoczesna nowoczesność biografii (s. 249-273). Lublin: TN KUL.

Kuźniak, A. (2013). Papusza. Wołowiec: Wydawnictwo Czarne.

Łotman, J. (1983). Semiotyka filmu. Warszawa: Wiedza Powszechna.

Machowska, M. (2014). Romska poetka Bronisława Wajs-Papusza. Miedzy mitem a biografią. Pobrane z: http://spolecznieodpowiedzialni.pl/files /file/a8n4r1yqvjm0cj6j40ulaoooyotvoq.pdf.

Machowska, M. (2011). Bronisława Wajs-Papusza. Między biografią a legendą. Kraków: Zakład Wydawniczy „NOMOS”.

Michałek, B. (1976). Ćwiczenia z anatomii kina. Warszawa: Wydawnictwa Artystyczne i Filmowe.

Michałek, B. (2007). Biografia filmowa - dziś. W: T. Szczepański, S. Kołos (red.). Biografistyka filmowa. Ekranowe interpretacje losów i faktów (s. 302-305). Toruń: Wydawnictwo Adam Marszałek.

Nochlin, L. (2007). Dlaczego nie było wielkich artystek? Pobrane z: http://www.unigender. org/?page=biezacy\&issue $\% 20=02$ \&article $=07$ "article $=07$.

Osęka, A. (1987). Mitologie artysty. Warszawa: Wiedza Powszechna.

Rosicka, A. (2014). Papusza według Joanny i Krzysztofa Krauzów. Pobrane z: http:// film.onet.pl/artykuly-i-wywiady/papusza-wedlug-joanny-i-krzysztofa-krauzowopowiesconieistniejacymswiecie/ 2twhb.

Szczepański, T., Kołos, S. (red.). (2007). Biografistyka filmowa. Ekranowe interpretacje losów i faktów. Toruń: Wydawnictwo Adam Marszałek.

Sochaj, A. (2013). Bronisława Wajs-Papusza. Życie i twórczość. Szczecinek: Związek Romów Polskich.

Sosnowska, J. (2005). Biografia kobieca. W: R. Kasperowicz, E. Wolicka (red.). Biografia, historiografia dawniej i dziś. Biografia nowoczesna nowoczesność biografii. Lublin: TN KUL.

Spyrka, K. (2013). Don Vasyl: Jesteśmy zbulwersowani filmem Papusza. Pobrane z: http:// blogi.dziennikzachodni.pl/poprostupytam/2013/11/28/don-vasyl-jestesmyzbulwersowan i-filmem-papusza-znow-ktos-chce-zarobic-na-kulturze-cyganskiej.

Szczepański, J. (1978). Sprawy ludzkie. Warszawa: Czytelnik.

Szczurowski, M. (2007). Film jako źródło przeszłości kulturowej. Spojrzenie historyka. W: G. Pełczyński, R. Vorbrich (red.), Obrazy kultur. Poznań: Wydawnictwo „Biblioteka Telgte”.

Wajs-Papusza, B. (1973). Pieśni mówione. Łódź: Wydawnictwo Łódzkie.

Wajs-Papusza, B. (1956). Pieśni Papuszy. Wrocław: Wydawnictwo Zakładu im. Ossolińskich. 